\title{
AN APPEAL FOR RECORDS
}

Aboriginals and Torres Strait Islanders have actively participated in all the conflicts in which Australia has been involved in the twentieth century, from Gallipoli to the recent war in the Persian Gulf. They have served as members of front line,units, as nurses, labourers, and in reconnaissance and patrol duties. Their contribution to Australia's armed services is as significant as that of any other group in Australian society.

Unfortunately this contribution is poorly represented in the collections of the Australian War Memorial, one of whose tasks is to develop and maintain a national collection of historical material. The private records sub-section of the War Memorial collects the records of individuals and organisations which are essentially private in nature, for example diaries and letters. Its objective in collecting and documenting these records is to allow future generations to see how individuals and communities responded in times of conflict, thereby complementing the holdings of official records.

Anyone who is interested in discussing the donation of private records, photographs, or any other material, or has any questions should contact:

\author{
Mr Michael O'Sullivan \\ Assistant Curator \\ Private Records \\ Australian War Memorial \\ GPO Box 345 \\ Canberra ACT 2601 \\ Telephone: (06) 2434326
}

